\title{
Restrukturisasi Organisasi dan Kualitas Pelayanan di Dinas Penanaman Modal Pelayanan Terpadu Satu Pintu Kota Makassar
}

\author{
Darwis $^{1 *}$, Mohamad Thahir Haning ${ }^{2}$, Nur Indrayati Nur Indar \\ ${ }^{1}$ Program Studi Administrasi Publik, Universitas Hasanuddin, Indonesia \\ ${ }^{2}$ Program Studi Administrasi Publik, Universitas Hasanuddin, Indonesia \\ ${ }^{3}$ Program Studi Administrasi Publik, Universitas Hasanuddin, Indonesia
}

\begin{abstract}
This study aims to determine the Organizational Restructuring and Service Quality in the One-Stop Integrated Service Investment Service in Makassar City. The type of research in this research is quantitative with a descriptive style. The population in this study are all people who take care of permits at DPMPTSP Makassar City. The sample in this study amounted to 75 people. The data collecting technique in this research is using a questionnaire. Then the collected data were analyzed descriptively quantitatively. This study's results indicate that the variable of organizational restructuring includes the complexity of 62.3, formalization of 62.2, and centralization of 61.9. Meanwhile, service quality variables include reliability 61.26, tangible 66.13, responsiveness 62.26, Assurance 58.53, and empathy 62.4.
\end{abstract}

Keywords: organizational restructuring, service quality

\begin{abstract}
Abstrak
Tujuan penelitian ini yaitu untuk mengetahui Restrukturisasi Organisasi dan Kualitas Pelayanan di Dinas Penanaman Modal Pelayanan Terpadu Satu Pintu Kota Makassar. Jenis penelitian dalam penelitian ini yaitu kauntitatif dengan tipe deskriptif. Populasi dalam penelitian ini yaitu seluruh masyarakat yang mengurus izin di DPMPTSP Kota Makassar. Adapun sampel dalam penelitian ini berjumlah 75 orang. Teknik pengempulan data dalam penelitian ini yaitu menggunakan kuesioner. Kemudian data yang terkumpul dianalisis secara deskriptif kuantitatif. Hasil penelitian ini menunjukkan bahwa variabel restrukturisasi organisasi, meliputi Kompleksitas sebesar 62.3, Formalisasi 62.2, dan sentralisasi sebesar 61.9. Sedangkan variabel kualitas pelayanan meliputi: reliability sebesar 61.26, tangible sebesar 66.13, responsiveness sebesar 62.26, Assurance sebesar 58.53 dan emphaty sebesar 62.4 .
\end{abstract}

Kata Kunci: restrukturisasi organisasi, kualitas pelayanan

\footnotetext{
*darwisdgseni17@gmail.com

DOI: https://doi.org/10.26618/kjap.v6i3.4352
} 


\section{PENDAHULUAN}

Struktur organisasi merupakan suatu susunan kepengurusan suatu kelompok masyarakat atau pemerintahan yang memiliki hubungan antara bagian yang satu dengan bagian yang lainnya pada suatu organisasi pemerintah maupun swasta untuk mencapai sebuah tujuan yang telah ditetapkan sebelumnya. Struktur organisasi ini juga, menjelaskan tentang fungsi dan tugas seseorang yang diamanahkan dalam struktur itu selama menjadi bagian dari organisasi tersebut. Sehingga seseorang mampu menyelesaikan suatu program atau kegiatan yang menyangkut masyarakat dalam organisasi itu sendiri maupun masyarakat secara umum.

Dalam organisasi, struktur juga menyangkut aturan mengenai tugas dari masing-masing orang sesuai dengan bidangnya dari semua kepengurusan yang terdapat dalam dinamika organisasi. Disini struktur organsasi meniscayakan adanya sebuah wakil dari masing-masing devisi untuk menempati bidang tertentu demi mengontrol dan menyelesaikan suatu program atau kegiatan yang menyangkut kepentingan masyarakat atau kelompok dalam suatu masyarakat. Oleh sebab itu, struktur organisasi memiliki peran yang sangat penting dalam organisasi untuk mencapai tujuannya.
Salah satu tujuan dari sebuah organisasi publik yaitu untuk memberikan pelayanan terhadap masyarakat sebagai bentuk tanggungjawab, fungsi dan tugas sehingga meningkatkan kepuasan masyarakat terhadap pelayanan tersebut.

Dalam proses pemberian pelayanan publik kepada masyarakat tentunya ada peran penting dari aparatur sipil negara yang memiliki fungsi dan tugas untuk memberikan pelayanan demi terwujudnya pemenuhan kebutuhan dalam pelayanan publik. Pemenuhan kebutuhan ini tentunya memberikan kepuasan tersendiri bagi masyarakat yang mendapatkan pelayanan yang berkualitas.

Salah satu bentuk upaya untuk meningkatkan kualitas pelayanan itu sendiri, yaitu dengan melakukan restrukturisasi organisasi. Restrukturisasi organisasi adalah aktivitas yang dilakukan organisasi untuk merubah proses dan kendali internalnya dari suatu hirarki vertikal fungsional yang tradisional, menjadi pipih yang horizontal, lintas fungsional dengan berlandaskan kerjasama tim yang berfokus pada proses dapat membuat organisasi lebih nyaman. Pandiangan dalam Huda, (2016).

Salah satu organisasi publik yang melakukan restrukturisasi organisasi sebagai upaya peningkatan kualitas pelayanan publik yaitu Dinas Penanaman Modal Pelayanan Terpadu Satu Pintu Kota 
Makassar sejak tahun 2017. Oleh sebab itu, penulis tertarik untuk melakukan penelitian yang berjudul Restrukturisasi Organisasi dan Kualitas Pelayanan Publik Di Dinas Penanaman Modal Pelayanan Terpadu Satu Pintu Kota Makassar.

Menurut Haning, (2015) salah satu dimensi yang menjadi bagian dalam organisasi adalah struktur yang merupakan susunan dari kepengurusan sebuah kelompok masyarakat atau pemerintahan. Dalam sebuah organisasi, struktur juga menyangkut aturan mengenai tugas dari masing-masing orang sesuai dengan bidangnya dari semua kepengurusan yang terdapat dalam dinamika organisasi. Sebagai bagian dari dimensi organisasi, keberadaan sangat menetukan terhadap kelancaran organisasi dalam melakukan controlling atau pengawasan terhadap setiap orang yang menempati bagian struktur organisasi.

Sejalan dengan itu Wisnu U.R, (2019) berpendapat bahwa struktur organisasi adalah system formal tentang hubungan tugas dan wewenang yang mengendalikan bagaimana tiap individu bekerjasama dan mengelola segala sumberdaya yang ada untuk mewujudkan tujuan organisasi. Tujuan prinsip dari struktur organisasi adalah sebagai alat kontrol; untuk mengendalikan koordinasi dan motivasi kerja tiap individu dalam usaha mencapai tujuan organisasi. Bagi semua organisasi, sebuah struktur yang tepat adalah struktur yang mampu merespon banyak masalah koordinasi dan motivasi yang sewaktuwaktu bisa muncul baik di bagian lingkungan, teknologi, ataupun sumberdaya manusia. Di sisilain, menurut Robbins, (1999) struktur organisasi memiliki tiga komponen, yaitu: Kompleksitas (Complexity), Formalisasi (Formalization), dan Sentalisasi (Centralization). Kompleksitas ini terdiri dari jumlah spesialisasi pekerjaan, aktivitas yang profesional, dan pelatihan profesianal karyawan demi kemajuan suatu organisasi. Formalisasi mengacu pada suatu tingkat yang terhadapnya di dalam organisasi itu di bakukan.

Menurut Suryono, restrukturisasi dapat didefinisikan sebagai penataan ulang seluruh rancangan organisasi atau perubahan struktur suatu organisasi dan nilai agar sesuai dengan tujuan yang akan dicapai serta kondisi riil dan potensial yang dimiliki. Sedangkan restrukturisasi organisasi adalah suatu tindakan untuk meningkatkan efisiensi dan produktivitas. Selain itu Menurut Lilik, (2007) restrukturisasi diartikan sebagai bentuk dan tingkat kompetensi yang dapat dicapai oleh organisasi. Menjalankan restrukturisasi perlu serius, seserius ketika perusahaan hendak melakukan privatisasi.

Restrukturisasi organisasi merupakan salah satu upaya untuk meningkatkan 
kualitas pelayanan. Pelayanan publik menurut Undang-Undang Nomor 25 Tahun 2009 adalah kegiatan atau rangkaian kegiatan dalam rangka pemenuhan kebutuhan pelayanan sesuai dengan peraturan perundang-undangan bagi setiap warga negara dan penduduk atas barang, jasa, dan/ atau pelayanan administratif yang disediakan oleh penyelenggara pelayanan publik.

Sejalan dengan itu, Putra Yanuar, (2019) memaknai pelayanan publik sebagai suatu layanan yang disediakan oleh pemerintah kepada warga negara atau masyarakat, baik secara langsung maupun tidak langsung. Untuk mengetahui bagaimana pelayanan publik itu, tentu harus diketahui apa yang menjadi kriteria pelayanan publik itu sendiri.

Dalam memberikan pelayanan publik, instansi penyedia pelayanan publik harus memperhatikan asas pelayanan public Mahmudi dalam Sellang, Kamaruddin, (2019) yaitu: (1) Transparansi, yaitu pemberian pelayanan publik harus bersifat terbuka, mudah dan dapat diakses oleh semua pihak yang membutuhkan dan disediakan secara memadai serta mudah dimengerti. (2) Akuntabilitas, yaitu pelayanan publik harus dapat dipertanggungjawabkan sesuai dengan ketentuan peraturan perundang-undangan. (3) Kondisional, yaitu pemberian pelayanan publik harus sesuai dengan kondisi dan kemampuan pemberi dan penerima pelayanan dengan tetap berpegang pada prinsip efisiensi dan efektivitas. (4) Partisipatif, yaitu mendorong peran serta masyarakat dalam penyelenggaraan pelayanan publik dengan memperhatikan aspirasi, kebutuhan dan harapan masyarakat. (5) Tidak diskriminatif (kesamaan hak), yaitu pemberian pelayanan publik tidak boleh bersifat diskriminatif, dalam arti tidak membedakan suku, ras, agama, golongan, gender, status social dan ekonomi. (6) Keseimbangan hak dan kewajiban, yaitu pemberi dan penerima pelayanan publik harus memenuhi hak dan kewajiban masing-masing.

Selain asas pelayanan publik yang perlu diperhatikan, tapi juga menuntut tentang kualitas pelayanan itu sendiri. Sebagaimana pendapat yang dikemukakan oleh Hasbar dalam Sellang, Kamaruddin, (2019) bahwa pelayanan diberikan kepada masyarakat itu menuntut kualitas, pelayanan diselenggarakan oleh pemerintah melalui aparatnya, walaupun tidak bertujuan mencari keuntungan, namun tetap harus mengutamakan kualitas pelayanan sesuai tuntutan, harapan, dan kebutuhan masyarakat yang dilayani. Para aparatur (pegawai) haruslah menyadari posisi dan peran mereka sebagai pelayan publik. Bila dimata masyarakat kesan muncul tidak demikian, berarti tugas pelayanan yang diterima selama ini bukanlah produk 
pelayanan sepenuh hati, melainkan pelayanan yang hanya didasari kewajiban sebagai abdi negara.

Untuk meningkatkan kualitas pelayanan publik, tentunya kita harus mengetahui apa yang menjadi dimensi dari kualitas pelayanan itu sendiri. Menurut Vincent Gespersz dalam buku Mukarom, Zaenal \& Laksana, (2015) menyatakan bahwa peningkatan kualitas pelayanan meliputi dimensi-dimensi berikut: (1) Ketepatan waktu pelayanan berkaitan dengan waktu tunggu dan proses; (2) Akurasi atau ketepatan pelayanan; (3) Kesopanan dan keramahan pelaku bisnis; (4) Tanggung jawab dalam penanganan keluhan pelanggan; (5) Sedikit banyaknya petugas yang melayani dan fasilitas pendukung lainnya; (6) Berkaitan dengan lokasi, ruangan tempat pelayanan, tempat parkir, ketersediaan informasi, dan petunjuk/ panduan lainnya;

Berhubungan dengan kondisi lingkungan, kebersihan, ruang tunggu, fasiltas musik, AC, alat komunikasi, dan lain-lain.

Untuk mengukur bagaiamana tingkat kualitas pelayanan maka harus dipahami tentang indikator dari kualitas pelayanan itu sendiri. Menurut Parasuraman dalam Darwis, (2017) bahwa konsep kualitas layanan yang diharapkan, dirasakan dan ditentukan oleh kualitas layanan. Kualitas layanan tersebut terdiri dari daya tanggap, jaminan, bukti fisik, empati dan kehandalan.

Salah satu Organisasi Perangkat Daerah Kota Makassar yang melakukan restrukturisasi organisasi yaitu Dinas Penanaman Modal Pelayanan Terpadu Satu Pintu. Berdasarkan Peraturan Walikota Makassar No. 27 Tahun 2017 tentang penyelenggaraan pelayanan perizinan terpadu satu pintu: Pelayanan Perizinan Terpadu Satu Pintu, yang selanjutnya disingkat PTSP adalah pelayanan secara terintegrasi dalam satu kesatuan proses dimulai dari tahap permohonan sampai dengan tahap penyelesaian produk pelayanan melalui satu pintu.

Pelayanan Perizinan Terpadu Satu Pintu bertujuan: (1) Memberikan perlindungan dan kepastian hukum kepada masyarakat; (2) Memperpendek proses pelayanan; (3) Mewujudkan proses pelayanan yang cepat, mudah, murah, transparan, pasti, dan terjangkau; dan (4) Mendekatkan dan memberikan pelayanan yang lebih luas kepada masyarakat.

\section{METODE PENELITIAN}

Jenis penelitian yang digunakan dalam penelitian ini yaitu deskriptif kuantitatif. Penelitian kuantitatif dengan format deskriptif untuk menjelaskan, meringkaskan berbagai kondisi, berbagai situasi, atau berbagai variabel yang timbul di masyarakat yang menjadi objek 
penelitian itu berdasarkan apa yang terjadi.

Kemudian mengangkat ke permukaan karakter atau gambaran tentang kondisi, situasi, ataupun variable tersebut. Bungin, (2005).

Penelitian ini dilaksanakan di Kantor Dinas Penanaman Modal Pelayanan Terpadu Satu Pintu Kota Makassar dari bulan September - oktober 2020. Populasi dalam penelitian ini yaitu masyarakat yang mengurus perizinan dan sampel dalam penelitian ini berjumlah 75 orang.

Teknik pengumpulan data dalam penelitian ini menggunakan Angket. Angket atau kuesioner merupakan suatu teknik atau cara pengumpulan data secara tidak langsung (peneliti tidak langsung bertanya jawab dengan responden. Instrumen atau alat pengumpulan datanya juga disebut angket berisi sejumlah pertanyaan dan pernyataan yang harus dijawab atau direspon oleh responden.

Setelah data terkumpul, maka dilakukan Teknik analisis data. Teknik analisis data yang digunakan dalam penelitian ini yaitu analisis deskriptif. Analisis deskriptif merupakan analisis yang digunakan untuk menganalisis data dengan cara mendiskripsikan atau menggambarkan data yang telah terkumpul sebagaimana adanya tanpa bermaksud membuat kesimpulan yang berlaku untuk umum atau generalisasi.

\section{HASIL DAN PEMBAHASAN}

Dinas Penanaman Modal Pelayanan Terpadu Satu Pintu (DPMPTSP) merupakan unsur pelaksana urusan Pemerintahan dibidang penanaman modal dan pelayanan terpadu satu pintu yang menjadi kewenangan daerah. Kantor DPMPTSP Kota Makassar ini terletak di jalan Balai Kota no. 2, Baru, Kecamatan Ujung Pandang Kota Makassar. Dinas Penanaman Modal dan Pelayanan Terpadu Satu Pintu dipimpin oleh Kepala Dinas yang berkedudukan di bawah dan bertanggungjawab kepada Walikota melalui Sekretaris Daerah.

Susunan organisasi Dinas Penanaman Modal dan Pelayanan Terpadu Satu Pintu Kota, terdiri dari: (1) Kepala Dinas, (2) Sekretariat, (3) Bidang Kebijakan, Advokasi, Pengaduan, Data dan Sistem Informasi Layanan, (4) Bidang Perencanaan, Pengembangan dan Promosi Penanaman Modal, (5) Bidang Pengendalian Pelaksanaan Penanaman Modal, (6) Bidang Penyelenggaraan Pelayanan Perizinan dan Nonperizinan A, (7) Bidang Penyelenggaraan Pelayanan Perizinan dan Nonperizinan B, (8) Bidang Penyelenggaraan Pelayanan Perizinan dan Nonperizinan C, (9) Kelompok Jabatan Funsional, dan (10) Unit Pelaksana Teknis. Menurut Robbins, (1999) struktur organisasi memiliki tiga komponen, yaitu: Kompleksitas (Complexity), Formalisasi 
(Formalization), dan Sentalisasi (Centralization). Kompleksitas ini terdiri dari jumlah spesialisasi pekerjaan, aktivitas yang profesional, dan pelatihan profesianal karyawan demi kemajuan suatu organisasi. Formalisasi mengacu pada suatu tingkat yang terhadapnya di dalam organisasi itu di bakukan. Sentralisasi, mempengaruhi struktur organisasi yakni mengacu pada sampai tingkat mana pengambilan keputusan dipusatkan pada suatu titik tunggal dalam organisasi.

Berdasarkan data hasil penelitian yang telah dilakukan di Dinas Penanaman Modal Pelayanan Terpadu Satu Pintu Kota Makassar, maka dapat kita lihat dari analisis deskriptif kuantitatif jawaban responden mengenai pernyataan - pernyataan yang telah diberikan kepada responden di lapangan. Adapun indikator dalam penelitian ini yaitu restrukturisasi meliputi: kompleksitas, formalisasi dan sentralisasi. Sedangkan indikator kualitas pelayanan, meliputi: daya tanggap, jaminan, bukti fisik, empati dan kehandalan. Berdasarkan indikator ini, kemudian dianalisis secara deskriptif kuantitatif untuk mengetahui restrukturisasi organisasi dan kualitas pelayanan, untuk lebih jelasnya dapat kita lihat pada penjelasan sebagai berikut. Analisis ini dilakukan untuk mendapatkan gambaran deskriptif mengenai responden dalam penelitian ini, khususnya variabel variabel penelitian yang digunakan untuk mengukur restrukturisasi organisasi dan kualitas pelayanan di Dinas Penanaman Modal Pelayanan Terpadu Satu Pintu Kota Makassar. Dalam penelitian ini, kuesioner (Angket) yang dibagikan menggunakan skala likert dengan 5 skala pengukuran. Maka indeks perhitungan indeks jawaban responden dilakukan dengan rumus sebagai berikut:

Nilai Indeks $=\left(\left(1 \mathrm{xF}_{1}\right)+\left(2 \mathrm{xF}_{2}\right)+\right.$ $\left.\left(3 \mathrm{xF}_{3}\right)+\left(4 \mathrm{xF}_{4}\right)+\left(5 \mathrm{xF}_{5}\right)\right) /$ 5. Dimana:

$\mathrm{F}_{1}$ adalah frekuensi jawaban responden yang menjawab 1.

$\mathrm{F}_{2}$ adalah frekuensi jawaban responden yang menjawab 2.

$\mathrm{F}_{3}$ adalah frekuensi jawaban responden yang menjawab 3.

$\mathrm{F}_{4}$ adalah frekuensi jawaban responden yang menjawab 4.

$\mathrm{F}_{5}$ adalah frekuensi jawaban responden yang menjawab 5.

Pada kuesioner (angket) penelitian ini, angka jawaban responden tidak dimulai dari angka 0 (nol), melaingkan dari angka 1 - 5 (satu sampai lima). Jumlah pertanyaan dalam penelitian ini pada variabel restrukturisasi organisasi terdiri dari 9 pertanyaan dan dari variabel kepuasan masyarakat terdiri dari 15 pertanyaan. Total nilai indeks adalah 100 dengan menggunakan kriteria 3 kotak (three box method), maka rentang antara 20 - 100 sebesar 80 dan akan dibagi menjadi 3 sehingga menghasilkan rentang sebesar 
26.67. Nilai hasil rentang ini akan digunakan sebagi dasar interpretasi nilai indeks. Penggunaan 3 kotak (three box method) terbagi sebagai berikut (Ferdinand, 2006):

$73.36-100=$ Tinggi

$46.68-73.35=$ Sedang

$20.00-46.67=$ Rendah
Kompleksitas ini mengacu pada jumlah kegiatan atau subsistem dalam organisasi. Dalam kaitannya pada Dinas Penanaman Modal Pelayanan Terpadu Satu Pintu Kota Makassar ini diukur dengan dua indikator yaitu tingkatan proses dan pegawai yang memadai dalam memberikan pelayanan. Untuk lebih jelasnya maka dapat kita lihat pada tabel berikut:

Indeks Tanggapan Responden Mengenai

Kompleksitas

Tabel 1.

Tanggapan Responden Mengenai Kompleksitas

\begin{tabular}{|c|l|c|c|c|c|c|c|c|c|}
\hline \multirow{2}{*}{ No } & \multicolumn{1}{|c|}{ Indikator } & \multicolumn{5}{|c|}{ Skor } & Jumlah & Indeks & Kriteria \\
\cline { 2 - 8 } 1. & $\begin{array}{l}\text { Tingkatan poses untuk } \\
\begin{array}{l}\text { mendapatkan } \\
\text { pelayanan tidak ribet } \\
\text { dan berbelit-belit. }\end{array}\end{array}$ & 26 & 42 & 3 & 4 & 0 & 75 & 63 & Sedang \\
\hline 2. & $\begin{array}{l}\text { Pegawai sudah } \\
\text { memadai dalam } \\
\text { memberikan pelayanan } \\
\text { perizinan. }\end{array}$ & 21 & 44 & 7 & 3 & 0 & 75 & 61.6 & Sedang \\
\hline
\end{tabular}

Sumber: diolah dari data responden penelitian

Perhitungan indeks tanggapan responden mengenai kompleksitas adalah sebagai berikut:

Indikator $1=[(5 \times 26)+(4 \times 42)+(3 \times 3)+$ $(2 \times 4)+(1 \times 0)] / 5=63$

Indikator $2=[(5 \times 21)+(4 \times 44)+(3 \times 7)+$ $(2 \times 3)+(1 \times 0)] / 5=61.6$

Nilai Indeks $=(63+61.6) / 2=62.3$

Tanggapan responden sebagaimana tabel 1 menunjukkan bahwa Sebagian besar responden memberikan tanggapan setuju (S) terhadap aspek kompleksitas dari Dinas Penanaman Modal Pelayanan Terpadu Satu Pintu Kota Makassar, dengan nilai indeks 62.3. Artinya responden merasa mendapatkan pelayanan yang tidak berbelit-belit dan pegawai yang memberikan pelayanan cukup memadai. 
Indeks Tanggapan Responden Mengenai Formalisasi

Formalisasi ini mengacu pada pada peran pegawai dalam memahimi tugas dan fungsinya, hubungan antara pegawai dengan masyarakat, komunikasi yang terbangun antara pegawai dengan masyarakat dan proses perizinan yang mudah didapatkan oleh pemohon berbagai perizinan di Dinas Penanaman Modal Pelayanan Terpadu Satu Pintu Kota Makassar. Untuk lebih jelasnya dapat kita lihat pada tabel 2 sebagai berikut.

Tabel 2.

Tanggapan Responden Mengenai Formalisasi

\begin{tabular}{|c|c|c|c|c|c|c|c|c|c|}
\hline \multirow{2}{*}{ No } & \multirow{2}{*}{ Formalisasi } & \multicolumn{5}{|c|}{ Skor } & \multirow{2}{*}{ Jumlah } & \multirow{2}{*}{ Indeks } & \multirow{2}{*}{ Kriteria } \\
\hline & & SS & $S$ & $\mathrm{KS}$ & TS & STS & & & \\
\hline 1. & $\begin{array}{l}\text { Semua pegawai } \\
\text { memahami tugas dan } \\
\text { fungsinya masing- } \\
\text { masing dalam } \\
\text { memberikan } \\
\text { pelayanan. }\end{array}$ & 18 & 53 & 3 & 1 & 0 & 75 & 62.2 & Sedang \\
\hline 2. & $\begin{array}{l}\text { Hubungan antara } \\
\text { pegawai dengan } \\
\text { masyarakat dalam } \\
\text { memberikan pelayanan } \\
\text { terjalin dengan baik. }\end{array}$ & 16 & 53 & 3 & 2 & 1 & 75 & 61.2 & Sedang \\
\hline 3. & $\begin{array}{l}\text { Komunikasi yang baik } \\
\text { dari pegawai terhadap } \\
\text { masyarakat dalam } \\
\text { memberikan } \\
\text { pengarahan. }\end{array}$ & 21 & 46 & 5 & 2 & 1 & 75 & 61.8 & Sedang \\
\hline 4. & $\begin{array}{l}\text { Pegawai yang tidak } \\
\text { memberikan pelayanan } \\
\text { dengan baik, akan } \\
\text { diberikan sanksi. }\end{array}$ & 31 & 35 & 4 & 5 & 0 & 75 & 63.4 & Sedang \\
\hline 5. & $\begin{array}{l}\text { Proses pengajuan izin } \\
\text { oleh masyarakat } \\
\text { mudah dipahami dan } \\
\text { jelas }\end{array}$ & 21 & 49 & 3 & 0 & 2 & 75 & 62.4 & Sedang \\
\hline
\end{tabular}

Sumber: diolah dari data responden penelitian

Perhitungan indeks tanggapan Indikator $2=[(5 \times 16)+(4 \times 53)+(3 \times 3)+$ responden mengenai formalisasi adalah $(2 \times 2)+(1 \times 1)] / 5=61.2$ sebagai berikut:

Indikator $1=[(5 \times 18)+(4 \times 53)+(3 \times 3)+$ Indikator $3=[(5 \times 21)+(4 \times 46)+(3 \times 5)+$ $(2 \times 1)+(1 \times 0)] / 5=62.2$ $(2 \times 2)+(1 \mathrm{x} 1)] / 5=61.8$ Indikator $4=[(5 \times 31)+(4 \times 35)+(3 \times 4)+$ $(2 \times 5)+(1 \times 0)] / 5=63.4$ 
Indikator $5=[(5 \times 21)+(4 \times 49)+(3 \times 3)+$ $(2 \times 0)+(1 \times 2)] / 5=62.4$

Nilai Indeks=

$(62.2+61.2+61.8+63.4+62.4) / 5=62.2$

Tanggapan responden sebagaimana tabel 2 menunjukkan bahwa Sebagian besar responden memberikan tanggapan setuju (S) terhadap aspek formalisasi dari Dinas Penanaman Modal Pelayanan Terpadu Satu Pintu Kota Makassar, dengan nilai indeks 62.2. Artinya responden merasa pegawai yang memberikan pelayanan cukup memahami fungsi dan tugasnya masingmasing, pegawai mampu menjalin komunikasi yang baik kepada masyarakat yang membutuhkan pelayanan, pegawai cukup mampu mengarahkan masyarakat tentang pelayanan yang dibutuhkan, dan masyarakat cukup setuju apabila pegawai yang tidak memberikan pelayanan diberikan sanksi, serta proses pengajuan perizinan oleh masyarakat mudah dipahami.

\section{Indeks Tanggapan Responden Mengenai Sentralisasi}

Sentralisasi ini mengacu pada tingkat hierarkis yang memiliki kewenangan untuk membuat keputusan. Hal ini berjalan dengan baik apabila pegawai memahami perannya masing-masing dan koordinasi berjalan dengan baik antara pegawai Dinas Penanaman Modal Pelayanan Terpadu Satu Pintu Kota Makassar. Untuk lebih jelasnya dapat kita lihat pada tabel 3 sebagai berikut:

Tabel 3.

Tanggapan Responden Mengenai Sentralisasi

\begin{tabular}{|c|l|c|c|c|c|c|c|c|c|}
\hline \multirow{2}{*}{ No } & \multicolumn{1}{|c|}{ Sentralisasi } & \multicolumn{5}{|c|}{ Skor } & Jumlah & Indeks & Kriteria \\
\cline { 3 - 7 } 1. & $\begin{array}{l}\text { Peran pegawai dalam } \\
\text { memberikan pelayanan } \\
\text { sudah dijalankan } \\
\begin{array}{l}\text { sesuai dengan fungsi } \\
\text { dan tugas masing- } \\
\text { masing. }\end{array}\end{array}$ & 21 & 49 & 2 & 1 & 1 & 75 & 62 & Sedang \\
\hline 2. & $\begin{array}{l}\text { Koordinasi setiap } \\
\text { pegawai dalam } \\
\text { memberikan pelayanan } \\
\text { berjalan dengan baik. }\end{array}$ & 18 & 50 & 6 & 0 & 1 & 75 & 61.8 & Sedang \\
\hline
\end{tabular}

Sumber: diolah dari data responden penelitian

Perhitungan indeks tanggapan Indikator $1=[(5 \times 21)+(4 \times 49)+(3 \times 2)+$ responden mengenai sentralisasi adalah $(2 \times 1)+(1 \times 1)] / 5=62$ sebagai berikut:

Indikator $2=[(5 \times 18)+(4 \times 50)+(3 \times 6)+$ $(2 \times 0)+(1 \times 1)] / 5=61.8$ 
Nilai Indeks $=(62+61.8) / 2=619$

Tanggapan responden sebagaimana tabel 3 menunjukkan bahwa sebagian besar responden memberikan tanggapan setuju (S) terhadap aspek sentralisasi dari Dinas Penanaman Modal Pelayanan Terpadu Satu Pintu Kota Makassar, dengan nilai indeks 61.9. Artinya responden menganggap bahwa pegawai cukup memahami peran masing-masing dalam memberikan palayanan dan menilai bahwa koordinasi antara pegawai berjalan dengan baik pula.

Indeks Tanggapan Responden Mengenai Reliability
Reliability (keandalan) merupakan suatu kemampuan untuk memberikan jasa yang dijanjikan kepada penerima pelayanan. Seperti: kecermatan petugas dalam melayani, standar pelayanan yang jelas dan keahlian petugas dalam menggunakan alat bantu dalam proses pelayanan di Dinas Penanaman Modal Pelayanan Terpadu satu Pintu Kota Makassar. Untuk lebih jelasnya dapat kita lihat pada tabel 4 berikut ini:

Tabel 4

Tanggapan Responden Mengenai Reliability

\begin{tabular}{|c|c|c|c|c|c|c|c|c|c|}
\hline \multirow{2}{*}{ No } & \multirow{2}{*}{ Reliability (Keandalan) } & \multicolumn{5}{|c|}{ Skor } & \multirow{2}{*}{ Jumlah } & \multirow{2}{*}{ Indeks } & \multirow{2}{*}{ Kriteria } \\
\hline & & SS & $S$ & $\mathrm{KS}$ & $\mathrm{TS}$ & STS & & & \\
\hline 1. & $\begin{array}{l}\text { Pegawai cermat dalam } \\
\text { memberikan } \\
\text { pelayanan. }\end{array}$ & 15 & 55 & 3 & 0 & 2 & 75 & 61.2 & Sedang \\
\hline 2. & $\begin{array}{l}\text { Pegawai berdasar pada } \\
\text { standar pelayanan yang } \\
\text { jelas. }\end{array}$ & 15 & 51 & 5 & 3 & 1 & 75 & 60.2 & Sedang \\
\hline 3. & $\begin{array}{l}\text { Pegawai mampu dan } \\
\text { handal } \\
\text { mengoperasikan alat } \\
\text { bantu dalam } \\
\text { memberikan } \\
\text { pelayanan. }\end{array}$ & 21 & 48 & 4 & 1 & 1 & 75 & 62.4 & Sedang \\
\hline
\end{tabular}

Sumber: diolah dari data responden penelitian

Perhitungan indeks tanggapan responden mengenai reliability

(kehandalan) adalah sebagai berikut:

Indikator $1=[(5 \times 15)+(4 \times 55)+(3 \times 3)+$ $(2 \times 0)+(1 \times 2)] / 5=61.2$

Indikator $2=[(5 \times 15)+(4 \times 51)+(3 \times 5)+$ $(2 \times 3)+(1 \times 1)] / 5=60.2$
Indikator $3=[(5 \times 21)+(4 \times 48)+(3 \times 4)+$ $(2 \times 1)+(1 \times 1)] / 5=62.4$

Nilai Indeks $=(61.2+60.2+62.4) / 3=61.26$

Tanggapan responden sebagaimana tabel 4 menunjukkan bahwa Sebagian besar responden memberikan tanggapan setuju (S) terhadap aspek reliability (kehandalan) 
dari Dinas Penanaman Modal Pelayanan Terpadu Satu Pintu Kota Makassar, dengan nilai indeks 61.26. Artinya responden merasa pegawai cukup handal dalam memberikan pelayanan kepada masyarakat.

\section{Indeks Tanggapan Responden Mengenai} Tangible

Tangible (bukti fisik), merupakan suatu bentuk penampilan fisik, peralatan, media komunikasi, dan hal-hal lainnya yang berbentuk fisik dalam upaya memberikan pelayanan yang maksimal kepada masyarakat. Seperti: kenyamanan ruang tunggu, kemudahan proses dan akses layanan, serta ketersediaan loket pelayanan. Untuk lebih jelasnya dapat kita lihat pada tabel 5 berikut ini.

Tabel 5.

Tanggapan Responden Mengenai Tangible

\begin{tabular}{|c|l|c|c|c|c|c|c|c|c|}
\hline \multirow{2}{*}{ No } & Tangible (Bukti Fisik) & SS & S & KS & TS & STS & Jumlah & Indeks & Kriteria \\
\cline { 3 - 7 } 1. & $\begin{array}{l}\text { Ruang menunggu } \\
\text { untuk mendapatkan } \\
\text { pelayanan memberikan } \\
\text { rasa nyaman dalam } \\
\text { mengurus perizinan }\end{array}$ & 37 & 32 & 4 & 1 & 1 & 75 & 65.6 & Sedang \\
\hline 2. & $\begin{array}{l}\text { Proses dan akses untuk } \\
\text { mendapatkan layanan } \\
\text { perizinan sudah jelas. }\end{array}$ & 28 & 39 & 6 & 1 & 1 & 75 & 63.4 & Sedang \\
\hline & $\begin{array}{l}\text { Loket pelayanan } \\
\text { tersedia ditata dengan } \\
\text { baik yang dilengkapi } \\
\text { dengan petunjuk yang } \\
\text { jelas. }\end{array}$ & 26 & 45 & 2 & 2 & 0 & 75 & 64 & Sedang \\
\hline
\end{tabular}

Sumber: diolah dari data responden penelitian, 2020.

Perhitungan indeks tanggapan responden mengenai tangible (bukti fisik) adalah sebagai berikut:

Indikator $1=[(5 \times 37)+(4 \times 32)+(3 \times 4)+$ $(2 \times 1)+(1 \times 1)] / 5=65.6$

Indikator $2=[(5 \times 28)+(4 \times 39)+(3 \times 6)+$ $(2 \times 1)+(1 \times 1)] / 5=63.4$

Indikator $3=[(5 \times 26)+(4 \times 45)+(3 \times 2)+$ $(2 \times 2)+(1 \times 0)] / 5=64$
Nilai indeks $=(65.6+63.4+64) / 3=66.13$

Tanggapan responden sebagaimana tabel 5 menunjukkan bahwa Sebagian besar responden memberikan tanggapan setuju (S) terhadap aspek tangible (bukti fisik) di Dinas Penanaman Modal Pelayanan Terpadu Satu Pintu Kota Makassar, dengan nilai indeks 66.13. Artinya responden merasa cukup nyaman menunggu dalam mengurus perizinan dengan ketersediaan 
loket pelayanan dan prosedur mendapatkan pelayanan cukup jelas.

\section{Indeks Tanggapan Responden Mengenai Responsiveness}

Responsiveness (daya tanggap), merupakan suatu respon atau daya tanggap aparatur palayanan publik dalam membantu masyarakat dan memberikan pelayanan yang cepat dan tanggap. Daya tanggap ini mencakup, respon terhadap setiap pemohon dengan cepat dan tepat, kemampuan memberikan pelayanan dengan cepat dan mampu merespon terhadap berbagai keluhan atas pelayanan yang dirasakan oleh masyarakat. Lebih jelasnya dapat dilihat pada tabel berikut ini.

Tabel 6.

Tanggapan Responden Mengenai Responsiveness

\begin{tabular}{|c|c|c|c|c|c|c|c|c|c|}
\hline \multirow{2}{*}{ No } & \multirow{2}{*}{$\begin{array}{c}\text { Responsiveness (Daya } \\
\text { Tanggap) }\end{array}$} & \multicolumn{5}{|c|}{ Skor } & \multirow{2}{*}{ Jumlah } & \multirow{2}{*}{ Indeks } & \multirow{2}{*}{ Kriteria } \\
\hline & & SS & $S$ & $\mathrm{KS}$ & TS & STS & & & \\
\hline 1. & $\begin{array}{l}\text { Pegawai merespon } \\
\text { setiap pemohon } \\
\text { perizinan dengan cepat } \\
\text { dan tepat. }\end{array}$ & 24 & 43 & 5 & 3 & 0 & 75 & 62.6 & Sedang \\
\hline 2. & $\begin{array}{l}\text { Pegawai mampu } \\
\text { memberikan pelayanan } \\
\text { dengan cepat. }\end{array}$ & 21 & 48 & 3 & 3 & 0 & 75 & 62.4 & Sedang \\
\hline 3. & $\begin{array}{l}\text { Pegawai mampu } \\
\text { merespon setiap } \\
\text { keluhan yang diberikan } \\
\text { oleh penerima layanan. }\end{array}$ & 20 & 49 & 1 & 5 & 0 & 75 & 61.8 & Sedang \\
\hline
\end{tabular}

Sumber: diolah dari data responden penelitian, 2020.

Perhitungan indeks tanggapan responden mengenai responsiveness (daya tanggap) adalah sebagai berikut:

Indikator $1=[(5 \times 24)+(4 \times 43)+(3 \times 5)+$ $(2 \times 3)+(1 \times 0)] / 5=62.6$

Indikator $2=[(5 \times 21)+(4 \times 48)+(3 \times 3)+$ $(2 \times 3)+(1 \times 0)] / 5=62.4$

Indikator $3=[(5 \times 20)+(4 \times 49)+(3 \times 1)+$ $(2 \times 5)+(1 \times 0)] / 5=61.8$

Nilai Indeks $=(62.6+62.4+61.8) / 3=62.26$

Tanggapan responden sebagaimana tabel 6 menunjukkan bahwa Sebagian besar responden memberikan tanggapan setuju (S) terhadap aspek responsiveness (daya tanggap) di Dinas Penanaman Modal Pelayanan Terpadu Satu Pintu Kota Makassar, dengan nilai indeks 62.26. Artinya responden menilai pegawai cukup tanggap dalam memberikan pelayanan terhadap masyarakat yang mengurus perizinan. 
Indeks Tanggapan Responden Mengenai Assurance

Assurance (jaminan), merupakan suatu bentuk jaminan yang diberikan oleh pemberi pelayanan kepada masyarakat penerima pelayanan atas kebutuhan baik itu dari segi keramahan, kesopanan, keterampilan dalam memberikan pelayanan dan mampu untuk meyakinkan masyarakat dalam pelayanan yang maksimal. Selanjutnya dapat kita pamahi dalam tabel berikut ini.

Tabel 7.

Tanggapan Responden Mengenai Assurance

\begin{tabular}{|c|l|c|c|c|c|c|c|c|c|}
\hline No & Assurance (Jaminan) & \multicolumn{5}{|c|}{ Skor } & Jumlah & Indeks & Kriteria \\
\cline { 2 - 8 } 1. & $\begin{array}{l}\text { Pegawai memberikan } \\
\text { jaminan tepat waktu } \\
\text { dalam pelayanan } \\
\text { perizinan. }\end{array}$ & 11 & 45 & 15 & 4 & 0 & 75 & 57.6 & Sedang \\
\hline 2. & $\begin{array}{l}\text { Pegawai memberikan } \\
\text { jaminan legalitas } \\
\text { dalam pelayanan } \\
\text { perizinan. }\end{array}$ & 12 & 53 & 8 & 2 & 0 & 75 & 60 & Sedang \\
\hline 3. & $\begin{array}{l}\text { Pegawai memberikan } \\
\text { jaminan kepastian } \\
\text { biaya dalam } \\
\text { pelayanan perizinan. }\end{array}$ & 11 & 50 & 8 & 5 & 1 & 75 & 58 & Sedang \\
\hline
\end{tabular}

Sumber: diolah dari data responden penelitian, 2020.

Perhitungan indeks tanggapan responden mengenai assurance (jaminan) adalah sebagai berikut:

Indikator $1=[(5 \times 11)+(4 \times 45)+(3 \times 15)+$ $(2 \times 4)+(1 \times 0)] / 5=57.6$

Indikator $2=[(5 \times 12)+(4 \times 53)+(3 \times 8)+$ $(2 \times 2)+(1 \times 0)] / 5=60$

Indikator $3=[(5 \times 11)+(4 \times 50)+(3 \times 8)+$ $(2 \times 5)+(1 \times 1)] / 5=58$

Nilai Indeks $=(57.6+60+58) / 3=58.53$

Tanggapan responden sebagaimana tabel 7 menunjukkan bahwa Sebagian besar responden memberikan tanggapan setuju
(S) terhadap aspek assurance (jaminan) di Dinas Penanaman Modal Pelayanan Terpadu Satu Pintu Kota Makassar, dengan nilai indeks 58.53. Artinya responden menilai pegawai cukup memberikan jaminan terhadap masyarakat, seperti tepat waktu, legalitas dan kepastian biaya.

\section{Indeks Tanggapan Responden Mengenai} Emphaty

Emphaty (empati), merupakan kemudahan dalam membangun relasi, komunikasi yang baik, perhatian pribadi dan pemahaman atas kebutuhan 
masyarakat. Untuk lebih jelasnya dapat kita

lihat pada tabel berikut ini.

Tabel. 8.

Tanggapan Responden Mengenai Emphaty

\begin{tabular}{|c|c|c|c|c|c|c|c|c|c|}
\hline \multirow{2}{*}{ No } & \multirow{2}{*}{ Emphaty (Empati) } & \multicolumn{5}{|c|}{ Skor } & \multirow{2}{*}{ Jumlah } & \multirow{2}{*}{ Indeks } & \multirow{2}{*}{ Kriteria } \\
\hline & & SS & $\mathrm{S}$ & $\mathrm{KS}$ & $\mathrm{TS}$ & STS & & & \\
\hline 1. & $\begin{array}{l}\text { Pegawai } \\
\text { mendahulukan } \\
\text { kepentingan pemohon }\end{array}$ & 18 & 49 & 6 & 2 & 0 & 75 & 61.6 & Sedang \\
\hline 2. & $\begin{array}{l}\text { Pegawai memberikan } \\
\text { pelayanan dengan } \\
\text { sikap yang ramah, } \\
\text { sopan dan santun. }\end{array}$ & 25 & 44 & 3 & 2 & 1 & 75 & 63 & Sedang \\
\hline 3. & $\begin{array}{l}\text { Pegawai melayani dan } \\
\text { menghargai setiap } \\
\text { orang yang } \\
\text { membutuhkan } \\
\text { pelayanan. }\end{array}$ & 20 & 51 & 2 & 1 & 1 & 75 & 62.6 & Sedang \\
\hline
\end{tabular}

Sumber: diolah dari data responden penelitian, 2020.

Perhitungan indeks tanggapan responden mengenai emphaty (empati) adalah sebagai berikut:

Indikator $1=[(5 \times 18)+(4 \times 49)+(3 \times 6)+$ $(2 \times 2)+(1 \times 0)] / 5=61.6$

Indikator $2=[(5 \times 25)+(4 \times 44)+(3 \times 3)+$ $(2 \times 2)+(1 \times 1)] / 5=63$

Indikator $3=[(5 \times 20)+(4 \times 51)+(3 \times 2)+$ $(2 \times 1)+(1 \times 1)] / 5=62.6$

Nilai Indeks $=(61.6+63+62.6) / 3=62.4$

Tanggapan responden sebagaimana tabel 8 menunjukkan bahwa Sebagian besar responden memberikan tanggapan setuju (S) terhadap aspek Emphaty di Dinas Penanaman Modal Pelayanan Terpadu Satu Pintu Kota Makassar, dengan nilai indeks 62.4. Artinya responden menilai pegawai cukup berempati terhadap masyarakat dalam memberikan pelayanan kepada masyarakat.

\section{KESIMPULAN}

Berdasarkan hasil penelitian yang telah dilakukan maka dapat disimpulkan bahwa Restrukturisasai organisasi dan kualitas pelayanan di Dinas Penanaman Modal Pelayanan Terpadu Satu Pintu Kota Makassar cukup baik. Hal ini dilihat dari variabel penelitian restrukturisasi, meliputi Kompleksitas sebesar 62.3, Formalisasi 62.2, dan sentralisasi sebesar 61.9. Sedangkan variabel kualitas pelayanan meliputi: reliability sebesar 61.26, tangible sebesar 66.13, resvonsiveness sebesar 62.26, Assurance sebesar 58.53 dan emphaty sebesar 62.4 . 


\section{DAFTAR PUSTAKA}

Bungin, B. (2005). Metodologi Penelitian Kuantitatif: Komunikasi, Ekonomi, dan Kebijakan Publik Serta Ilmu Ilmu-Ilmu Sosial Lainnya. Kencana.

Darwis. (2017). Hubungan kualitas pelayanan dengan Kepuasan Masyarakat pengguna Bus Rapid Transit (BRT) Maminasata. Kolaborasi, Volume 32.

Haning, M. T. (2015). Reformasi Birokrasi (Desain Organisasi yang Mendukung Pelayanan Publik Di Indonesia). Ilmu Giri Yogyakarta.

Huda, S. (2016). Pengaruh Penerapan Restrukturisasi Organisasi, Pemanfaatan Teknologi Informasi Dan Komunikasi Serta Penyempurnaan Sumberdaya Manusia Terhadap Kepatuhan Wajib Pajak. Jurnal Manajemen Dan Kewirausahaan, Volume $4 \mathrm{~N}$.

Lilik, A. M. L. (2007). Human Capital Competencies (Sketsa - Sketsa Praktik Hukum Capital Berbasis Kompetensi. PT. Elex Media Komputindo.

Mukarom, Zaenal \& Laksana, M. W. (2015). Manajemen Pelayanan Publik. Pustaka Setia.

Robbins, S. P. (1999). Organization Theory (Structure, Design and Aplications). Third Edition. San Diego State University.

Sellang, Kamaruddin, dkk. (2019). Strategi Dalam Peningkatan Kualitas Pelayanan Publik (Dimensi, Konsep, Indikator Dan Implementasi). Qiara Media.

Suryono. (2011). Manajemen Sumber Daya Manusia (Etika dan Standar Profesional Sektor Publik). UB Press.

Wisnu U.R, D. (2019). Teori Organisasi (Struktur dan Desain). UMM Press.

Yanuar, R. M. (n.d.). Inovasi Pelayanan Publik (Studi Kasus: Public Safety Center (PSC) 119 Kabupaten Bantul sebagai Layanan Kesehatan dan Kegawatdaruratan). Jurnal Ilmu Pemerintahan, Vol. 4 